\title{
ART AND PROPAGANDA IN AN AGE OF WAR: THE ROLE OF POSTERS
}

\section{Lt R. Chambers*}

\section{Introduction}

Posters in this country have become one of the many means of communicating ideas; the message can be manipulative and they thus become a means of persuasion. They (can) reflect the mood of the times, the styles of their creators, they can be used to sell ideas and commodities and, (in the case of political posters), be used as a vehicle for the ideas of politicians and propagandists. Because they serve the (political) purpose of the moment, posters, like most other propaganda materials - pamphlets, banners, radio and TV broadcasts, leaflets, films, etc - are ephemeral and disposable.

In a war situation the problem is how to mobilize people and make them aware of their immediate tasks and goals. At the outbreak of World War II Germany, Russia, Italy and France had a well developed propaganda 'machine', whilst the Allies dragged behind in this respect. All these nations were quick to realize the important role propaganda would play in the war; as a means of maintaining political and social cohesion, and maintaining morale and enthusiasm for the war. Propaganda to boost the morale of your own citizens had to be combined with propaganda intended to counteract that which was directed at your citizens by the enemy.

The function of posters was to inform, instruct, or suggest new ways of looking at the war. Their central ideas had either to correspond to the mentality and ideas of the viewer, or had to manipulate his ideas in a positive or negative manner. The idea or message had to be easily comprehended by the target audience. Its appeal was more emotional than rational.

The layout of a poster had to be striking and able to capture one's attention immediately; it had to draw attention in a certain direction, and in a certain sequence; its message had to be clear and capable of holding attention long enough for the message to sink in. (Some people argue that a poster's message must be taken in in six seconds.) Most successful posters use a minimum of type; the exception being 'informational' posters - one's attention is attracted to the poster long enough for you to get interested in reading all its information.

Posters also have a maximum period of impact (dependent on how often a person views a poster); if a person views a poster continually or daily a poster loses its effect after approximately two weeks. This necessitates a continual renewal of interest, with future posters reinforcing the message of those which preceded them. In addition the message of a poster campaign will constantly be affected by changing events in, for example, the war front.

\section{Categorization of War Poster Types}

For the purpose of this article the posters under discussion will be categorized according to their function.

a. Posters which appeal to the patriotism of those who view it and which attempt to motivate them to contribute to the war effort.

b. Posters concerning the war effort. These are mainly civilian-orientated and not specifically military, emphasizing the civilian/military interrelationship. They deal with the production of war material, the incorporation of women into the labour force, or campaigns to collect funds to finance the war.

c. Posters which make a negative statement about the enemy. This section contains the horror and atrocity posters used to instill hate and fear for the enemy in the citizens.

\section{Categories of War Posters}

\section{A. The Appeal to The Patriotism of The Citizens}

In the war situation mass propaganda had to aim at the largest part of the population and convince it to be utterly loyal to the state. At the same time the state was making demands on the people which, in peacetime, would have been intolerable. The strain must not lead to disloyalty, nor political doubt and dissent to treason; patriots 
had to defend their country and do their national duty. Without such loyalty a war could not be fought.

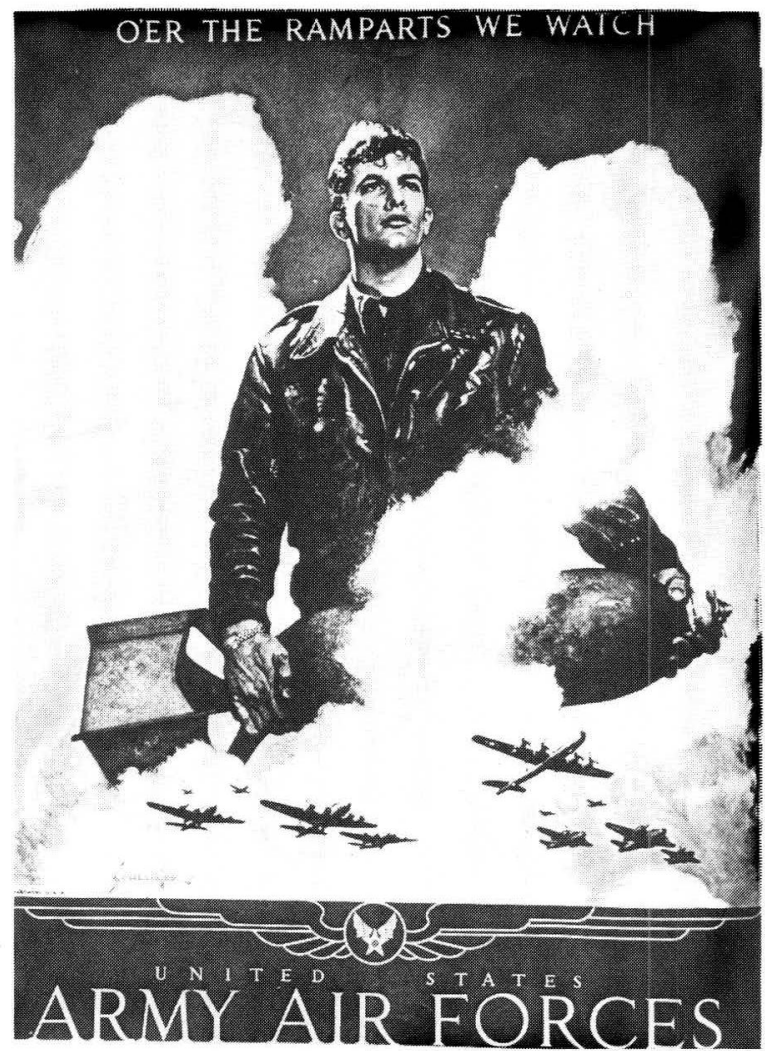

1.

“O'ER THE RAMPARTS"

U.S.A. (1944)

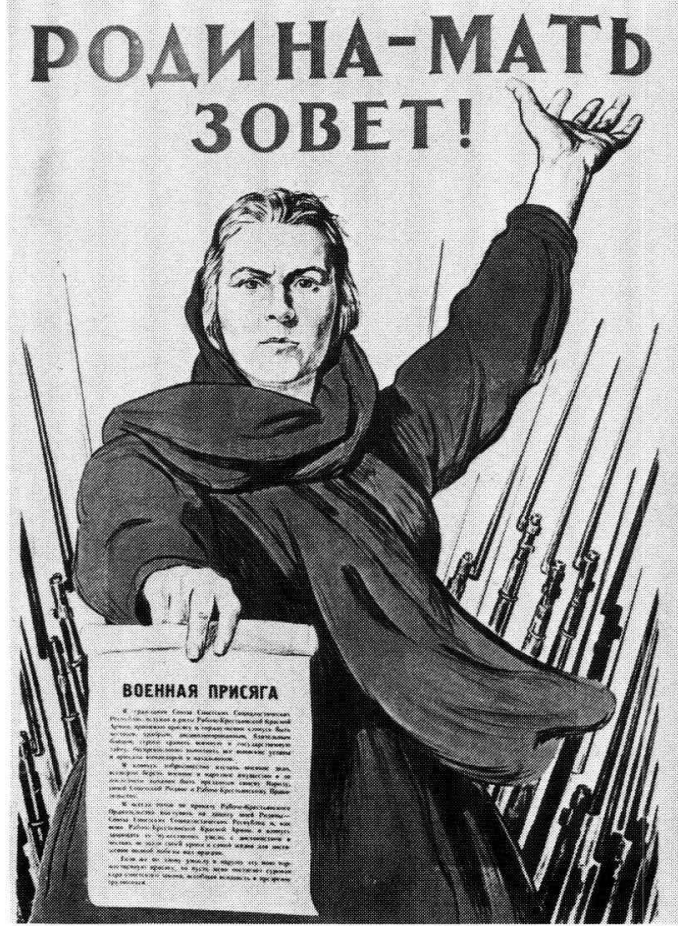

3.

“YOUR MOTHER COUNTRY

APPEALS TO YOU"

Russia. (1941)
The posters in this category, produced by the four major warring protagonists either aim at a direct recruitment of men for the war effort or, (in

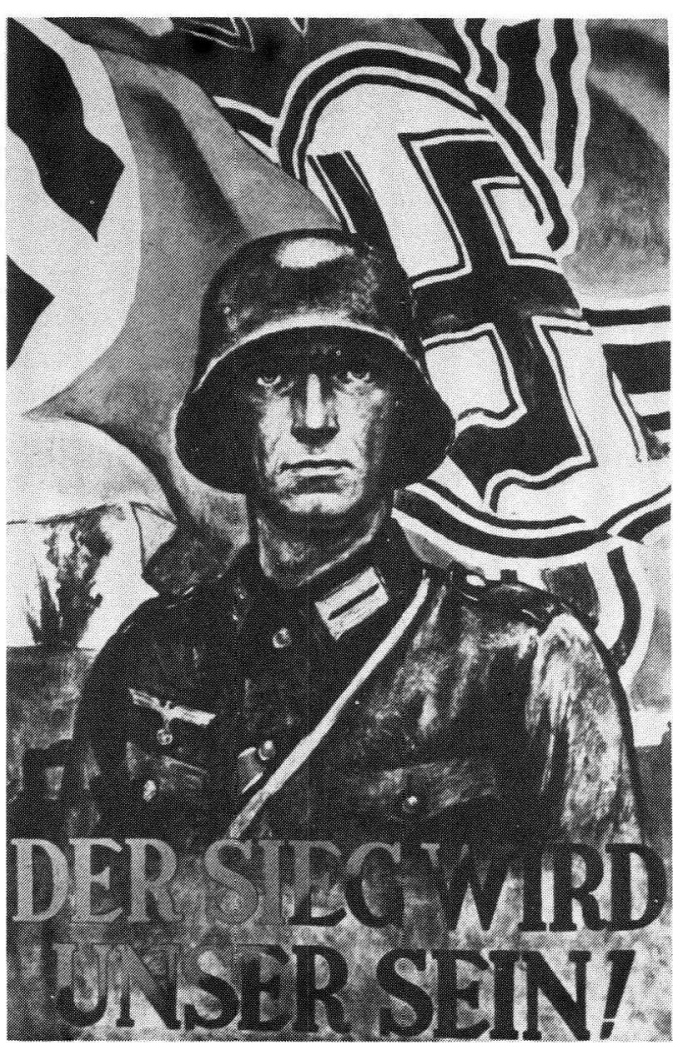

$2 . \quad$ "VICTORY WILL BE OURS"

Germany. (1942)

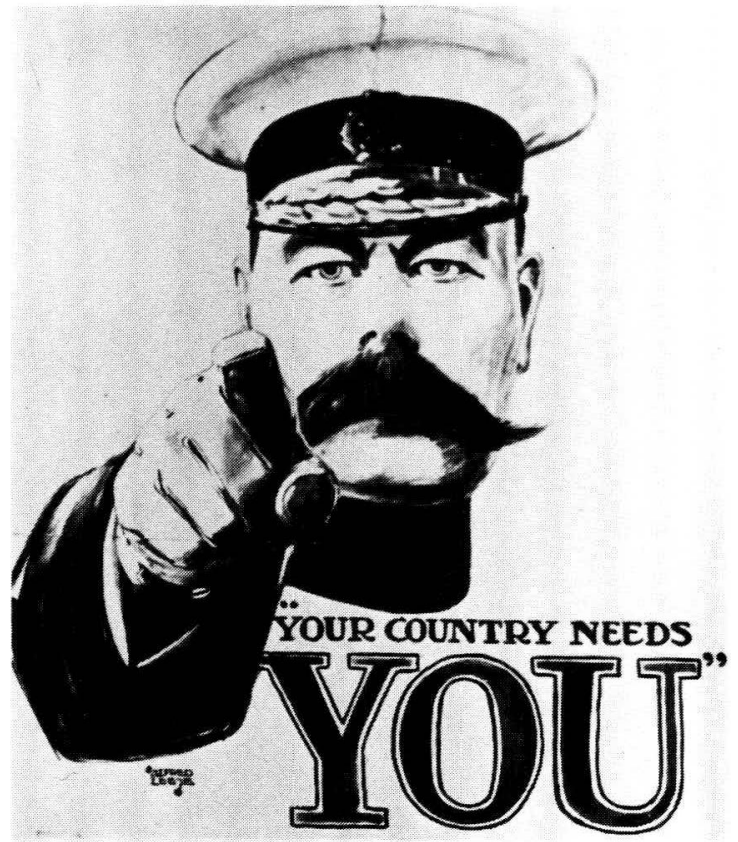

237 alfred leete Your Country Needs You I9I4

\section{4. "YOUR COUNTRY NEEDS YOU" Great Britain. (1914)}


the case of figure 4), to propagate a positive attitude towards national conscription. The German and American examples both employ rather idealized males in fighting uniform; not representing particular people but conveying the idea of archetypal representatives of their nation, gazing, not at the viewer of the poster, but into the future, with confidence. Both these posters employ national patriotic symbols, most popular on this type of poster; the German example uses the flag motif and swastika emblem, the American example displays a line from the 'STAR SPANGLED BANNER' which creates the link-up to an American patriotic background. The badge of the U.S. Army Airforce also provides an identifying logo.

The British and Russian examples use figures

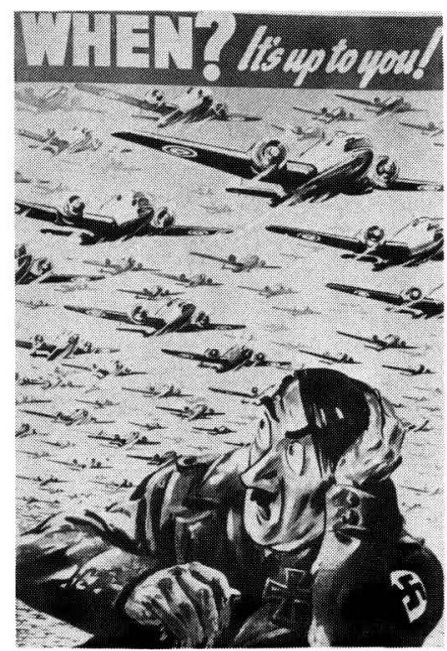

5. "WHEN? IT'S UP TO YOU" Great Britain

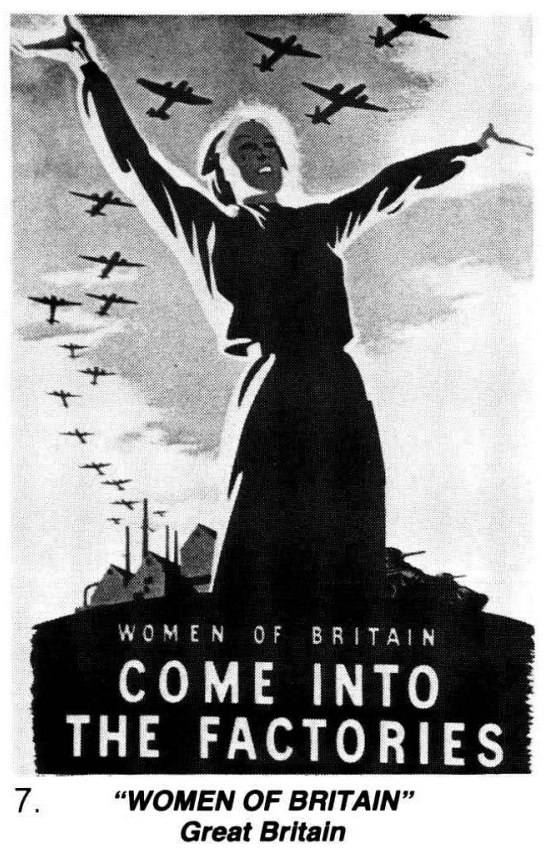

who directly address the persons who view the poster. The British poster shows a pointing finger and hand with the head of Lord Kitchener, the Recruiting General. The pointing finger and the eyes directly confront the viewer who is the 'you' in large, emphatic type. The Russian example uses a female figure who personifies the concept of 'Mother Russia.' Her raised hand directs the spectator's view towards the wording 'YOUR MOTHER COUNTRY APPEALS TO YOU!', her other hand thrusts out the text of the Russian military oath.

All four examples have used highly emotive means to communicate their ideas to the spectator.

\section{B. The Campaign for War Production}

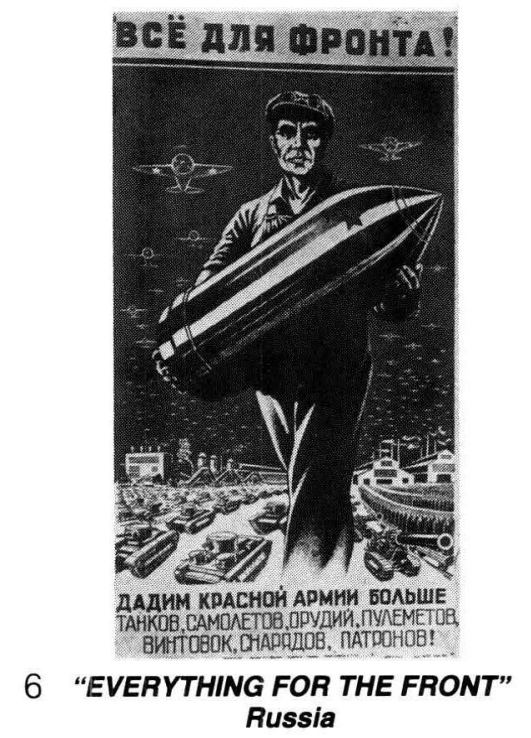

In a war in which civilians could change place with soldiers at short notice, the link between the home front and the military fronts were very close. In any case, the distinction between the civilian hinterland and the front line was blurred because many towns and industries of the nations at war were within reach of enemy bombers.

As a result of a tremendous increase in arms production the war effort required as forceful a mobilization of manpower as mobilization for the armed forces did. A poster campaign resulted as part of this mobilization process. The posters in this category closely resemble those appealing to patriotism, but are more specialized and are aimed directly at a civilian population. Generally they stress the parallel between the frontline soldier and the factory worker, and point to the dependence of the soldier on the worker. 
Many of them established the connection between financial sacrifice (taking the form of war bonds) and war production.

The effect of these posters had to be positive; they had to stress the technological nature of the war and emphasize that large quantities of war material were being produced (as seen in figures 5 and 6). This type of poster additionally act as a morale-booster for the civilian population: the masses of war material shown on the poster reinforces the idea that large-scale arms production is taking place, the cartoon image of Hitler fleeing from the mass of bombers (note the satirical handling of Hitler); the confidence with which the Russian worker strides forward (backed up by all the arms in the background).

But war production meant, in the first case, labour recruitment; manpower being replaced or extended by womenpower. The British example, 'WOMEN OF BRITAIN', shows the contribution women could make to the war effort.

\section{National Security}

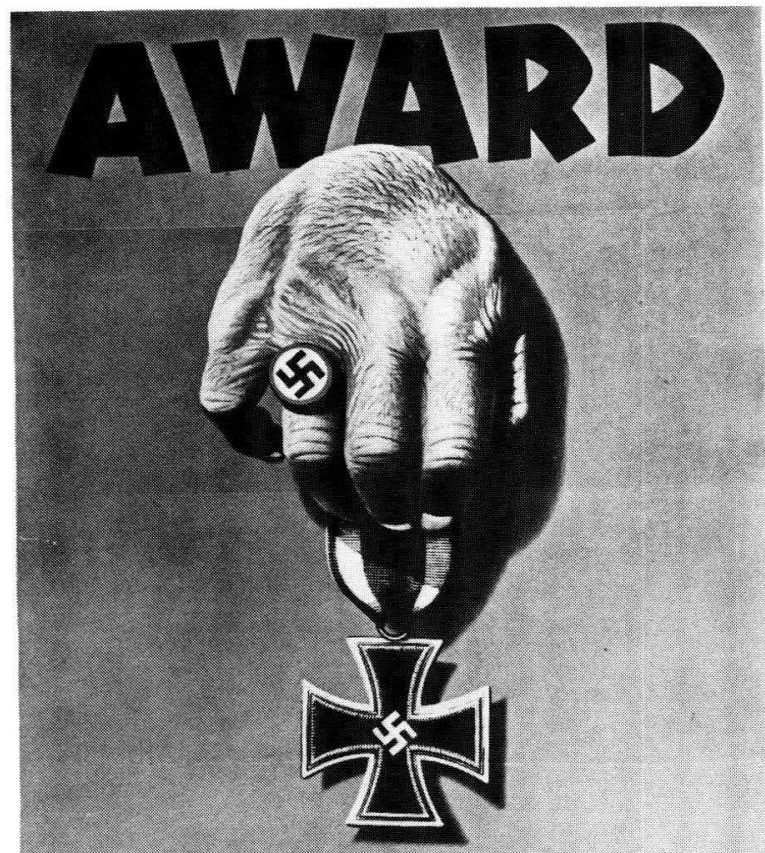

\section{FOR CARELESS TALK}

DONT DIICUIS TROOP MOVEMENTS - SHIP SAILINGS - WAR EQUIPHENT

8. “AWARD FOR CARELESS TALK” U.S.A.

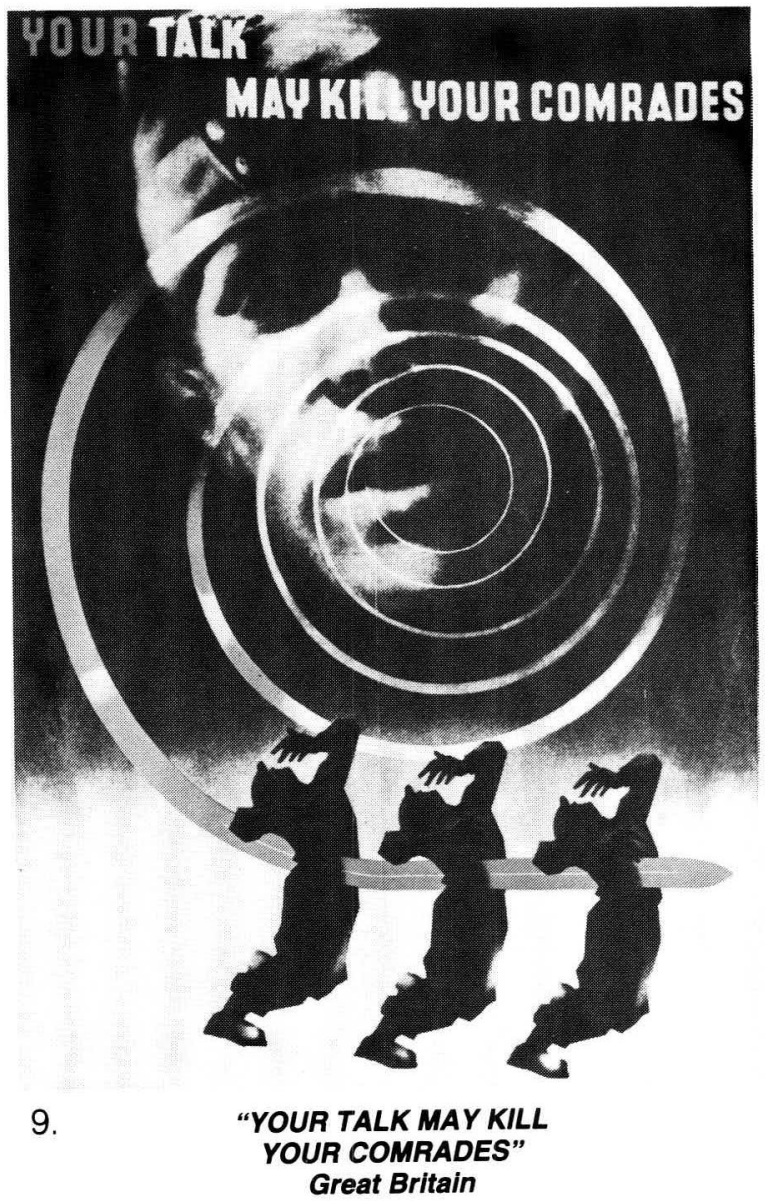

If the government sees the state as being beleaguered by enemies, external or internal, it then has to take appropriate measures. These include intelligence and internal security organizations, secret police etc. Thus a need for a type of poster that made appeals on behalf of military or war-industry security which concentrated on the enemy 'within', encouraging a mild form of mass paranoia - the feeling that the state was being besieged from within. Most of the national security posters were concerned with the effect of information leakage on the military effort.

In the previous section the appeal to (patriotic group) loyalty, a positive appeal, was discussed; concern with national security is a matter of warning. This category of poster could not use the patriotic symbols (flags etc) of the nation making the poster, but used the symbols of the enemy - a technique which focused people's attention to the dangers from the other side. The American poster 'AWARD FOR CARELESS TALK' shows a detached hand (wearing a Nazi ring) presenting a German Iron cross to, implicitly, a person who divulges information which will assist the enemy - thus an appeal to patriotism in reverse by creating a sense of guilt in the spectator. 
The poster designers who tackled the theme of national security simply had to be more inventive than the designers of other types of posters; they certainly experimented more. Photomontage (used in the British poster 'YOUR TALK MAY KILL YOUR COMRADES') and cartoons were two preferred techniques. In the two posters illustrated in this section the ultimate outcome and the cause - careless talk - are graphically linked.

\section{War Atrocities}

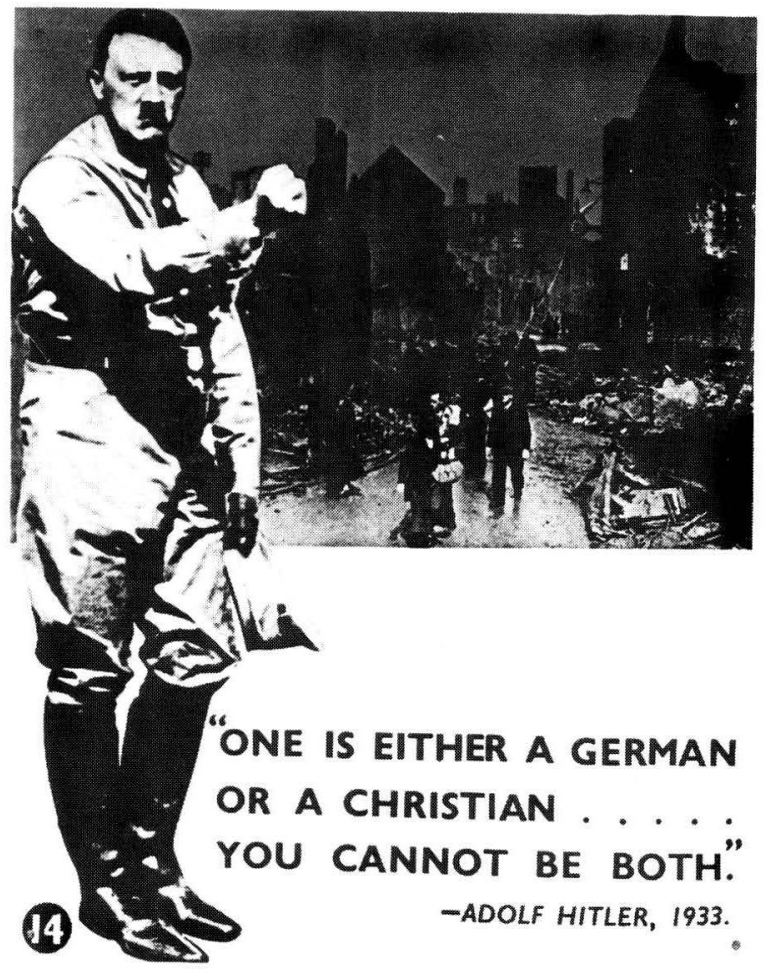

10.

\section{“ONE IS EITHER A GERMAN ..." Great Britain}

The posters which dealt with national security appeal to fear; the posters dealing with war atrocities played on people's hatred as well as their fears. In order to be cohesive a nation has, to some extent, to be exclusive; the barriers of language, habits, colours, etc have always tended to divide people into 'them' and 'us'. In wartime this tendency becomes necessarily stronger; the world is visibly divided.

In the two World Wars posters used the atrocity theme frequently; the enemy was inhuman, brutal and could not be trusted to behave in a humanitarian manner. For example a quote by Hitler; 'one is either a German or a Christian ... you cannot be both', has been used in the British

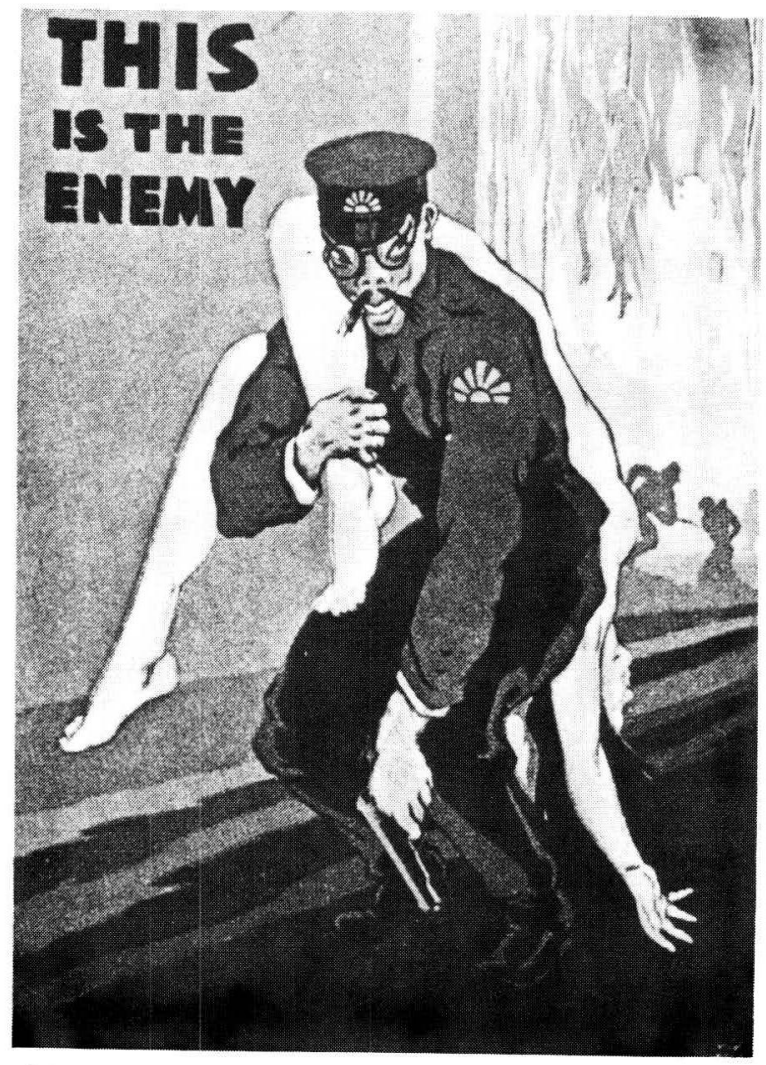

11.

"THIS IS THE ENEMY"

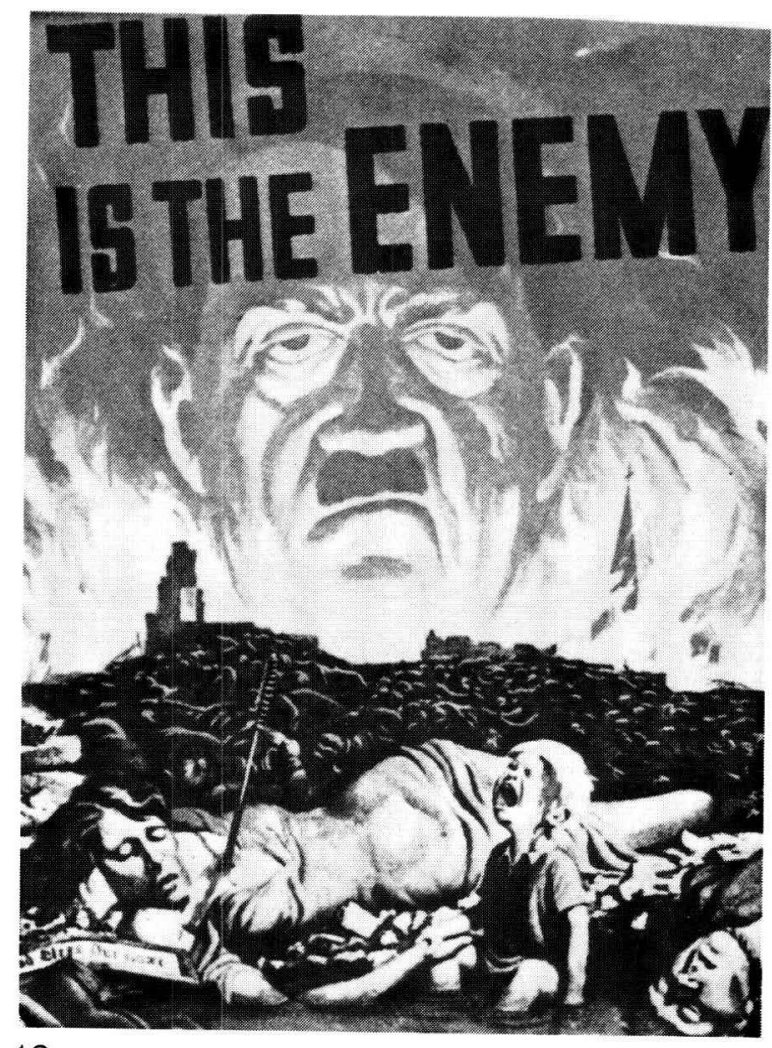

12
"THIS IS THE ENEMY" 
poster (figure 10). The quote has been taken out of the context of its original statement and placed within the new context of a photograph of Hitler in an aggressive pose, juxtaposed with an image of a bombed British residential area (with bewildered citizens), the sky area is replaced by a blood-red backdrop. These elements, in combination, provide a new meaning which is evident. This poster could be described as an example of 'soft' atrocity propaganda.

Figures 11 and 12 show that the propaganda of atrocity usually employes harsher elements.
*Lt R. Chambers is a NSM stationed at COLET. He has obtained the degrees BA HED and BA Honours in Art over the period 1976 to 1980 at Wits whereafter he taught for one year. After the completion of his National Service he intends to go back to the teaching profession.

\section{Sources Consulied/Further Reading}

Judd, D. Posters of World War II London: Mayland Publishers; 1972.

Barnicoat, J. A Concise History of Posters London: Thames and Hudson; 1979.

Zeman, Z. Selling the War: Art and Propaganda in World War II London: Orbis Publishing, 1979. 